\title{
Trophic State Evaluation of a Large Mediterranean Lake Utilizing Abiotic and Biotic Elements
}

\author{
George Kehayias", Evangelia Doulka
}

Department of Environmental and Natural Resources Management, University of Patras, Agrinio, Greece. Email: "gkechagi@upatras.gr, "gkechagi@cc.uoi.gr

Received September $21^{\text {st }}, 2013$; revised October $23^{\text {rd }}, 2013$; accepted November $19^{\text {th }}, 2013$

Copyright (C) 2014 George Kehayias, Evangelia Doulka. This is an open access article distributed under the Creative Commons Attribution License, which permits unrestricted use, distribution, and reproduction in any medium, provided the original work is properly cited. In accordance of the Creative Commons Attribution License all Copyrights (C) 2014 are reserved for SCIRP and the owner of the intellectual property George Kehayias, Evangelia Doulka. All Copyright (c) 2014 are guarded by law and by SCIRP as a guardian.

\section{ABSTRACT}

The trophic state of a freshwater ecosystem reflects its environmental quality. This is why several trophic indicators have been developed for such water bodies based on chemical, physical and biological parameters. Apart from that, there are several biotic elements which can be used in accessing the environmental condition of a freshwater ecosystem. Zooplankton organisms are important elements of the structure and function of lakes and are considered useful indicators of alterations in their trophic dynamics and ecological state related to changes in nutrient loading and climate. In accordance to the above, the present study is an attempt to assess the trophic condition of the largest lake in Greece (Lake Trichonis) through the investigation of the physicochemical elements, along with the biotic indications provided by a three-year study of the lake's zooplankton. The present results, compared with previous studies conducted between 15 and 25 years before, showed that there was an increase in the maximum values of the concentrations of chlorophyll- $\alpha$ and nutrients, while there was a decrease in water transparency. The implementation of Carslon's trophic state index (TSI) revealed that Lake Trichonis still remains an oligo-to mesotrophic ecosystem as it was in the past. However, although the zooplankton investigation showed several features that are common in oligotrophic lakes, there are certain eutrophic characteristics of the zooplankton community (e.g. abundance variation pattern, indicator species, seasonal succession of cladocerans) pointing out a different state of the ecosystem in comparison to the past. In conclusion, the use of a biotic element like zooplankton revealed that Lake Trichonis is experiencing a transitional condition towards the eutrophic state and points out the necessity for constant inspection and monitoring of this ecosystem.

\section{KEYWORDS}

\section{Lake Zooplankton; Eutrophication; Abundance; Trichonis Lake; Indicator Species; Mediterranean}

\section{Introduction}

Eutrophication of freshwater ecosystems such as natural lakes and reservoirs is a major environmental problem. Generally, eutrophication is the result of nutrient overenrichment of the water originated from natural processes such as decomposition of organic matter and sediment nutrient release, or to land-based activities and external nutrient loading (e.g. agricultural activities, sewage and industrial discharges, atmospheric releases from fossil fuel combustion, etc.). Agricultural activities are consi-

${ }^{*}$ Corresponding author. dered as the major provider of nutrients in lakes, especially in the Mediterranean region, where agricultural sector comprises an important economic factor [1]. Eutrophication involves a change in a lake's status from a macrophyte-dominated clear water state to a phytoplankton-dominated turbid state, with severe effects to the ecosystem like changes in the structure and trophic interactions among phytoplankton, zooplankton and benthic communities.

The growing need for the control of nutrient enrichment and pollution leads the European Union to the establishment of the Water Framework Directive (2000/60/ 
EC) in order to achieve a "good quality" in all European water bodies. Several indicators, indexes and models have been developed to assess eutrophication and water quality in aquatic ecosystems based on chemical, physical and biological parameters. Carlson's trophic state index (TSI) is the most widely used in freshwater bodies [2]. The index uses phytoplankton biomass estimated indirectly by chlorophyll- $\alpha$ pigment concentrations, water transparency (by the use of Secchi depth) and total phosphorus concentrations. The TSI index ranges from 0 to 100 , although theoretically there are no lower or upper boundaries. TSI values less than 40 correspond to oligotrophic conditions, while between 40 and 50 for mesotrophic and between 50 and 70 for eutrophic. Finally, index values greater than 70 are associated with hypertrophic conditions.

Except from direct measurements of physicochemical and biological elements, there are several biotic indicators which can be used in accessing the environmental quality of a water body [3]. Thus, in contrast to the instant evaluation of the state of an ecosystem provided by the measurements of physicochemical parameters, the biotic indicators have the advantage to show the influence of the chronic affection of the environmental disturbance to the structure of the aquatic communities, as it comes from the conditions existed before the measurements. In this way, the use of biotic indicators can be more useful in prediction of the evolution of the quality of an aquatic ecosystem. Zooplankton organisms are important elements of the structure and function of lakes, as they occupy a critical position between phytoplankton and higher consumers like fishes within the trophic web [4]. Its strategic position in the aquatic ecosystems, as well as its sensitivity to both man-made and natural changes, makes zooplankton quite suitable for biological monitoring of water quality [5]. Zooplankton is still not included as a biological quality parameter for aquatic ecosystems according to the implementation of the EU Water Framework Directive, though there are several studies that have shown its usefulness as an indicator of alterations in the trophic dynamics and the ecological state of lakes related to changes in nutrient loading and climate [6].

Lake Trichonis is the largest natural lake in Greece, having a surface area of $98.6 \mathrm{~km}^{2}$, a catchment area of $421 \mathrm{~km}^{2}$ and a potential water volume of approximately $2.868 \mathrm{~km}^{3}$ [7]. It is located in the prefecture of Aitoloakarnania in the western part of the country $\left(38^{\circ} 18^{\prime} \mathrm{N}\right.$ $38^{\circ} 511^{\prime} \mathrm{N}, 21^{\circ} 01^{\prime} \mathrm{E}-21^{\circ} 42^{\prime} \mathrm{E}$ ) at an altitude of $18 \mathrm{~m}$ a.s.l. It is a deep $\left(\mathrm{Z}_{\max }=57 \mathrm{~m}, \mathrm{Z}_{\text {mean }}=29 \mathrm{~m}\right)$ and warm monomictic lake, exhibiting a long period of thermal stratification. There are various surface water supplies (e.g. seasonal streams), as well as groundwater inflows (approx. $30 \%$ of the total annual water inflows), which provide an adequate quantity of water and resulted to positive water balance [7]. The excess of the lake's water is discharged through a sluice gate canal to the adjacent Lysimachia Lake to avoid potential flooding. From the biodiversity point of view, Lake Trichonis has great ecological importance and was included in the Natura 2000 protection network due to the priority habitat of calcareous fens (Cladium mariscus). Moreover, it has also great economic importance in respect to the use of water for irrigation purposes of the nearby agricultural areas, as well as to the commercial fishery of Atherina boyeri which is the dominant species in the fish community [8]. Around the lake there are several villages with a total population of about 35,000 people and the main economic activities are agriculture, livestock breeding and olive-oil refinery manufacturing. In the cathcment area of the lake there are $150 \mathrm{~km}^{2}$ of agricultural land (mainly tobacco, olive trees, cotton and corn), while there are also 33 operating olive-oil refineries that dispose their wastes untreated in septic tanks or directly in local streams. All the above activities, in combination with the lack of a wastewater treatment plant in the catchment area, imply significant organic pollution loads for the lake [1].

The environmental elements of Lake Trichonis and its trophic condition have been documented by several studies [1,9-11] in the past and according to them the lake has been classified as oligotrophic to mesotrophic. At the more recent report of Bertahas et al. [1], which compare data from two periods within a decade (19901991 and 2001-2002), the trophic state of the lake seemed to have altered from mesotrophic in the former period to oligotrophic in the latter, although the nutrients' concentrations have been greatly increased during this decade. This paradox was attributed to the particular hydrology of the lake by the above authors, who concluded that its trophic status is mainly hydrologically dependent and thus unpredictable [1]. On the other hand, there have been recent reports of the presence of zooplankton species in Lake Trichonis which are considered indicators of eutrophic conditions in other European lakes [12,13]. Consequently, all the above reports give a puzzling icon of the environmental state of the lake and, along with the given ecological and economic importance of this ecosystem, make the need for further investigation imperative.

Considering the above, through a three-year investigation (between 2003 and 2006), the present study aims to: 1) provide the most recent analytical data of the physicochemical environment and of the trophic state of the lake; 2) compare these recent data with the previous studies to assess its environmental state progress; 3) make an effort to combine abiotic and biotic (e.g. zooplankton) data in order to draw a more accurate picture of the present and possibly the future environmental 
quality of this ecosystem.

\section{Materials and Methods}

\subsection{Zooplankton Sampling and in Situ Measurements}

Three sampling stations (A, B and C) with depths of 48, 35 and $25 \mathrm{~m}$ respectively, were selected for data collection in Lake Trichonis (Figure 1). The overall sampling was carried out at monthly intervals during a three-year period from September 2003 to August 2006. Zooplankton samples were taken from all the sampling stations during the first two periods (September 2003-August 2005), while due to the lack of differences among the three stations (see bellow) and for logistic reasons, the samples were taken only from the deepest station A in the third period (September 2005-August 2006). The zooplankton was collected with a conical plankton net (40 cm in diameter, $100 \mathrm{~cm}$ in length, $50 \mu \mathrm{m}$ mesh size), which was modified to be a closing net with the addition of a second rope and a releasing trigger, analogous to those of the WP-2 closing net. Vertical hauls were conducted at $10 \mathrm{~m}$ depth intervals from the surface down to $40 \mathrm{~m}$, to $30 \mathrm{~m}$ and to $20 \mathrm{~m}$ for the stations $\mathrm{A}, \mathrm{B}$ and $\mathrm{C}$ respectively. The net was towed at a speed of approximately $0.5 \mathrm{~m} \cdot \mathrm{sec}^{-1}$. All samples were taken in the morning and were preserved in plastic bottles filled with $4 \%$ neutralized formalin solution.

In situ measurements of the physicochemical parameters were taken during the second sampling period (September 2004-August 2005) from all the three stations, while from just station A during the third period (September 2005-August 2006). Temperature, dissolved oxygen concentration (DO), $\mathrm{pH}$ and conductivity measurements were taken at $2 \mathrm{~m}$ intervals from the surface down to a maximum depth of $40 \mathrm{~m}$, using WTW portable instruments. Water transparency was measured with a Secchi disc.

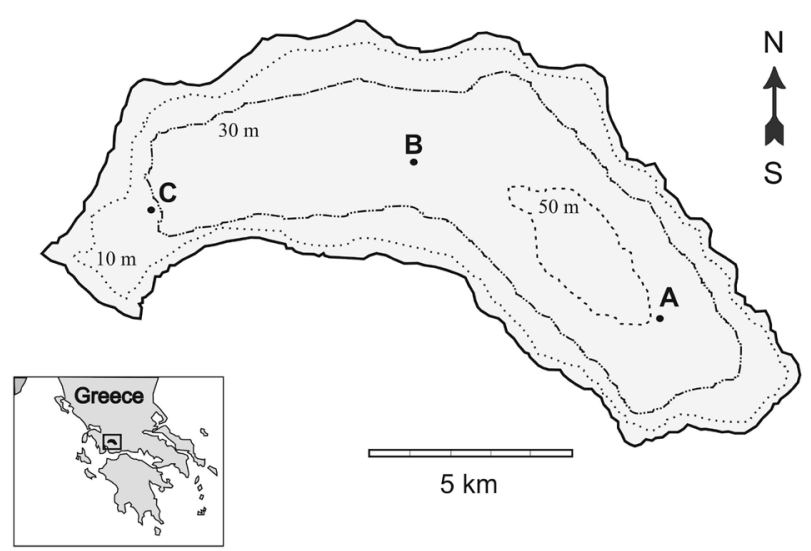

Figure 1. Lake Trichonis with the three sampling stations (A, B and C).

\subsection{Chemical Parameters and Chlorophyll- $\alpha$}

For the estimation of total phosphorus (TP), phosphates $\left(\mathrm{PO}_{4}\right)$, nitrates $\left(\mathrm{NO}_{3}\right)$, nitrites $\left(\mathrm{NO}_{2}\right)$ and ammonia $\left(\mathrm{NH}_{4}\right)$, water samples were collected at all stations (September 2004-August 2005) and at the deepest station A (September 2005-August 2006) from 0, 10, 20, 30 and $40 \mathrm{~m}$ with a 5 l Hydrobios water sampler. Analyses of all chemical parameters were performed according to APHA, AWWA \& WPCF [14]. For the determination of chlorophyll- $\alpha$ concentration (Chl- $\alpha$ ), $1500 \mathrm{ml}$ of the water samples taken from the above depths was filtered through a Whatman GF/A glass fibre filter shortly after collection. Pigment extraction was made in 90\% acetone and concentrations were determined spectrophotometrically [14]. Due to technical problems, no Chl- $\alpha$ measurements were taken in the period between September 2004 and February 2005.

\subsection{Trophic Classification}

The trophic classification of the lake was estimated using Carslon's [2] trophic state index (TSI) which utilizes chlorophyll-a (Chl-a), Secchi disk transparency (SD) and total phosphorus concentrations (TP). In particular, the TSI index for the three different quality variables such as Secchi depth $T S I_{S D}$, chlorophyll-a $T S I_{C h l-a}$ and total phosphorus $T S I_{T P}$ was calculated according to the equations:

$$
\begin{gathered}
\text { TSI }_{S D}=60-14.41 \times \ln (S D) \\
\text { TSI }_{C h l-a}=30.6+9.81 \times \ln (\text { Chl }-a) \\
T_{S I_{T P}}=4.15+14.42 \times \ln (T P)
\end{gathered}
$$

For $T S I_{C h l-a}$ and $T S I_{T P}$, the average epilimnetic (0 - 10 m) concentrations of Chl- $a$ and TP (both as $\mu \mathrm{g} \cdot \mathrm{l}^{-1}$ ) were used, while for the $T S I_{S D}$, the values of the Secchi disk (m) in each sampling station was used. The overall Carlson's TSI index was calculated as the average value of $T S I_{S D}, T S I_{C h l-a}$ and $T S I_{T P}$ in the three stations as follows:

$$
T S I=\frac{T S I_{S D}+T S I_{C h l-a}+T S I_{T P}}{3}
$$

\subsection{Zooplankton Analysis}

In the laboratory, the zooplankton specimens were examined microscopically and were identified to the lowest taxonomic level possible, using the keys of Rylov [15], Ruttner-Kolisko [16], Korovchinsky [17], Alonso [18] and Benzie [19]. For the abundance analysis, three counts of $1.5 \mathrm{ml}$ sub-samples from each sample were made on a Sedwick-Rafter cell having a total volume of $100 \mathrm{ml}$ [13]. The non-parametric Kruskal-Wallis test and the Mann-Whitney test (U-test) were used for assessing differences in the environmental parameters and in the 
abundance of zooplankton species and groups among sampling stations and sampling periods.

\section{Results and Discussion}

The temporal variations of the physicochemical parameters recorded in station A in Lake Trichonis during a two-year period (September 2004-August 2006) are presented in Figures 2 and 3. Station A is selected to be the most representative for the changes monitored along the entire water column of the lake, since it is the deepest station and considering the absence of statistically significant differences among the three sampling stations for almost any of the above parameters (Kruskal-Wallis test, $\mathrm{p}>0.05)$.

\subsection{In Situ Measurements}

Lake Trichonis is a deep, warm monomictic lake where

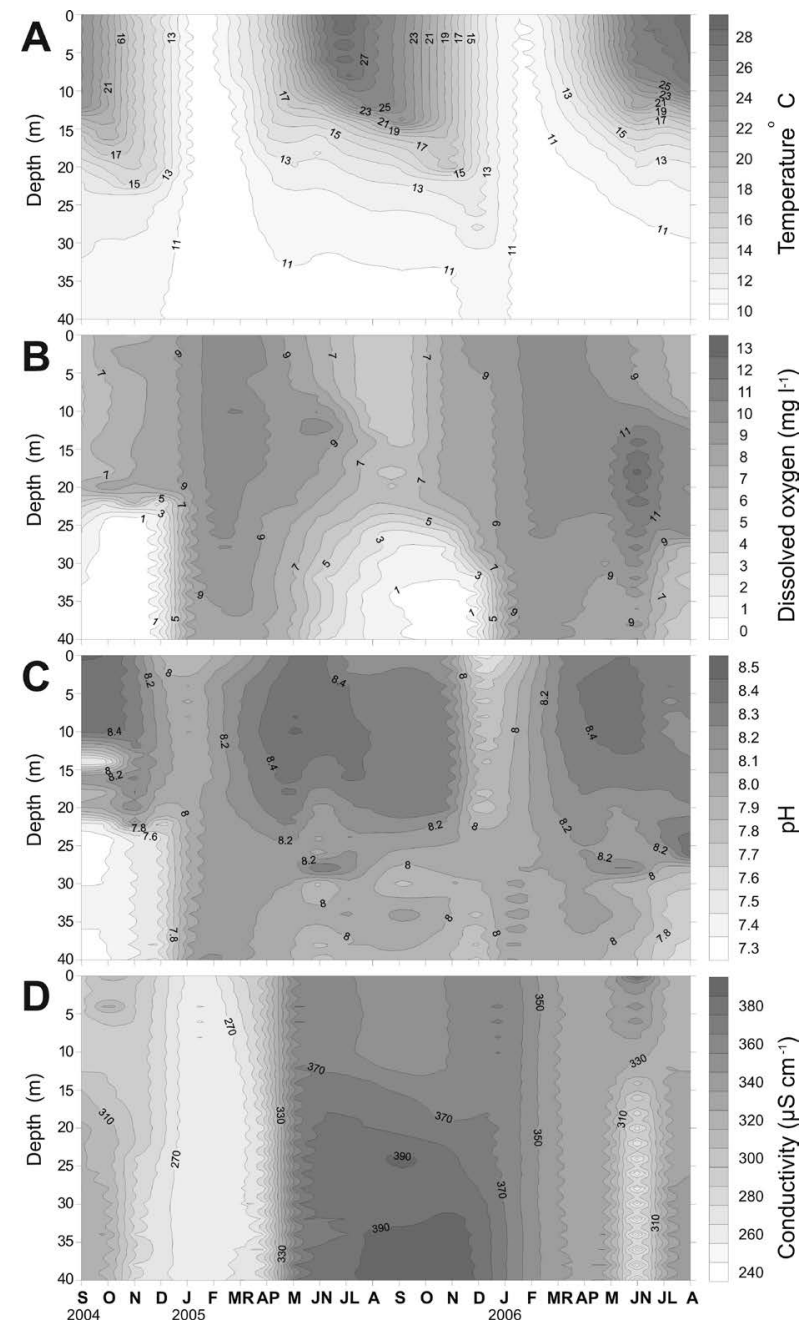

Figure 2. Vertical profiles of temperature (A), dissolved oxygen (B), pH (C) and conductivity (D) measured in situ in the deeper sampling station A of Lake Trichonis during September 2004 - August 2006.

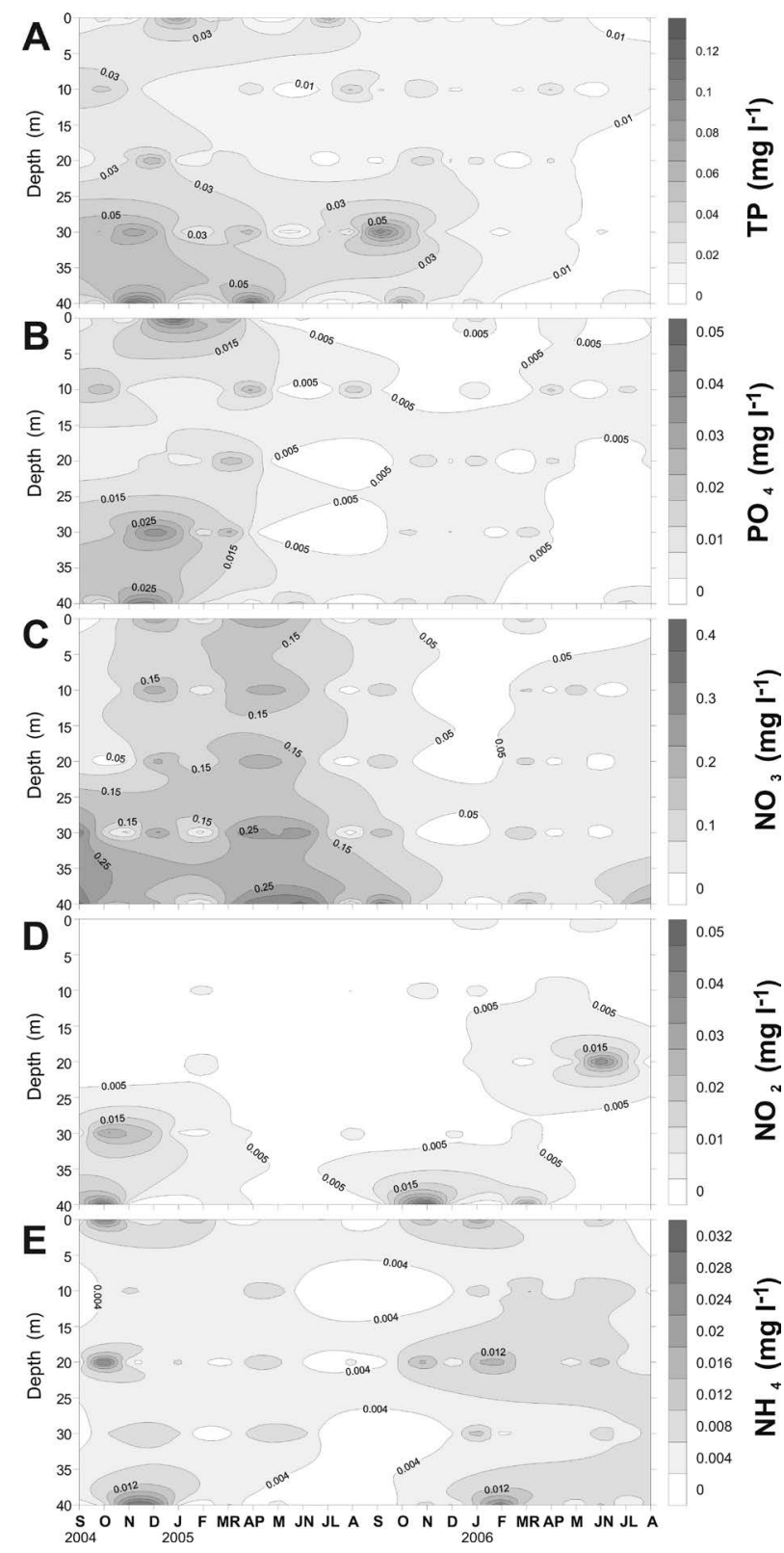

Figure 3. Vertical profiles of the concentrations of total phosphorus (A), phosphates (B), nitrates (C), nitrites (D) and ammonia (E) in the deeper sampling station $A$ of Lake Trichonis during September 2004 - August 2006.

the temperature variation leads to the development of a seasonal thermocline, causing highly stable water stratification within the lake. Temperature fluctuated between $10^{\circ} \mathrm{C}$ and $29.7^{\circ} \mathrm{C}$ (Figure 2) and there were no differences between the sampling periods and among the three sampling stations (Kruskal-Wallis test, $\mathrm{p}>0.05$ ). In comparison to the previous studies of Tafas et al. [11], Koussouris et al. [10] and Overbeck et al. [9] the maximum temperature value was greater by $2^{\circ} \mathrm{C}, 3.7^{\circ} \mathrm{C}$ and $5^{\circ} \mathrm{C}$ respectively (Table 1 ). Stratification of the lake started in April and the thermocline, which was created 
Table 1. Comparisons of the variation of the physicochemical parameters recorded in Lake Trichonis during the present study with analogous reports from previous studies.

\begin{tabular}{|c|c|c|c|c|}
\hline \multirow{2}{*}{ Parameter } & Present study & Tafas et al. & Koussouris et al. & Overbeck et al. \\
\hline & (2004-06) & (1997) & (1993) & (1982) \\
\hline Temperature $\left({ }^{\circ} \mathrm{C}\right)$ & $10-29.7$ & $9.5-27.5$ & $11.1-28.0$ & $10.0-25.0$ \\
\hline Dissolved oxygen $\left(\mathrm{mg} \cdot \mathrm{l}^{-1}\right.$ ) & $0.3-14$ & $3.7-12.0$ & $0.5-12.2$ & $2.0-12.0$ \\
\hline $\mathrm{pH}$ & $7.37-8.55$ & $7.6-8.5$ & $7.7-8.8$ & $8.1-8.5$ \\
\hline Conductivity $\left(\mu \mathrm{S} \cdot \mathrm{cm}^{-1}\right)$ & $247.5-398.2$ & $195-320$ & $230-270$ & $267-301$ \\
\hline Transparency (m) & $4-13$ & $4-11$ & $4-12.5$ & $5.7-13.9$ \\
\hline Chlorophyll- $\alpha\left(\mu \mathrm{g} \cdot \mathrm{l}^{-1}\right)$ & $0.2-9.4$ & $2.2-8.2$ & $2.3^{(1)}, 4.3^{(2)}$ & $0.5-0.8$ \\
\hline$T P\left(\mu \mathrm{g} \cdot \mathrm{l}^{-1}\right)$ & $1.5-131$ & $<7$ & $15^{(1)}, 66^{(2)}$ & $22-112$ \\
\hline $\mathrm{PO}_{4}\left(\mu \mathrm{g} \cdot \mathrm{l}^{-1}\right)$ & $0-95.2$ & $<20-70$ & $1-14$ & $2-40$ \\
\hline $\mathrm{NO}_{3}\left(\mathrm{mg} \cdot \mathrm{l}^{-1}\right)$ & $0-0.718$ & $0.05-0.45$ & $0.003-0.125$ & $0.02-0.232$ \\
\hline $\mathrm{NO}_{2}\left(\mathrm{mg} \cdot \mathrm{l}^{-1}\right)$ & $0-0.058$ & $0-0.005$ & $0.0013-0.018$ & $0.001-0.005$ \\
\hline $\mathrm{NH}_{4}\left(\mathrm{mg} \cdot \mathrm{l}^{-1}\right)$ & $0-0.035$ & $<0.01-0.09$ & $0.005-0.13$ & $0-0.062$ \\
\hline
\end{tabular}

${ }^{(1)}$ : Average value, ${ }^{(2)}$ : Max value.

within the 10 - 20 m layer, lasted until November. Turnover started to appear in December where the metalimnetic layer sinks to about $25 \mathrm{~m}$ and this gradual mixing of the water column lasted until the end of February. During turnover, and especially in January and February, temperature had a uniform distribution from the surface to the bottom of the lake (Figure 2).

The water transparency fluctuated between 4 and $13 \mathrm{~m}$ and presented higher values in the summer and lower in winter. The lowest transparency value of $4 \mathrm{~m}$ was equal to the respective value reported by Tafas et al. [11] and Koussouris et al. [10], and was recorder in winter at the shallowest station $\mathrm{C}$, which is influenced by the high amounts of water drainage entering into the lake in this period due to increased precipitation.

The water stratification in Lake Trichonis resulted to the presence of greater dissolved oxygen concentrations within the metalimnion, a feature common in deep stratified lakes [20]. The high transparency of the water during the summer period permitted the photosynthetic activity in the metalimnion, where the phytoplankton growth was benefited by the high nutrient concentrations released by decomposition processes. Indeed, the maximum concentration of dissolved oxygen was recorded in June 2006 (13.93 $\mathrm{mg} \cdot \mathrm{l}^{-1}$ ) within this layer as a result of oxygen produced by algal populations. During the stratification period the DO in the hypolimnetic layer decreased leading to hypoxic conditions (DO $<2 \mathrm{mg} \cdot \mathrm{l}^{-1}$ ) under the depth of $30 \mathrm{~m}$ in autumn. In contrast, during the winter turnover the lake was well oxygenated (DO between 8.30 and $10.85 \mathrm{mg} \cdot \mathrm{l}^{-1}$ ) throughout the entire water column (Figure 2). In comparison to the previous studies in the lake (Table 1 ), the maximum DO concen- tration recorded in the present study was higher and the minimum DO value was lower.

There was little variation in the $\mathrm{pH}$ values which fluctuated between 7.37 and 8.55 during the entire study period, while there were no significant differences with the previous studies (Table 1 ). In the vertical axis, higher $\mathrm{pH}$ values were recorded in the epilimnion during the stratified period, while they were almost constant in the whole water column during the mixing period (Figure 2).

Conductivity fluctuated between 247.5 and $398.2 \mu \mathrm{S}$. $\mathrm{cm}^{-1}$, with higher values in the hypolimnion during the stratification period, while during the mixing period there was little conductivity variation with depth (Figure 2). It must be pointed that, the values in the third sampling period (September 2005-August 2006) were considerably greater than the second one (September 2004-August 2005), although this was not statistically significant (U-test, p > 0.05). Considering the previous studies of Tafas et al. [11], Koussouris et al. [10] and Overbeck et al. [9], there was an increase of the highest value of conductivity by $24.4 \%, 47.5 \%$ and $32.3 \%$, respectively (Table 1).

\subsection{Chemical Parameters and Chlorophyll- $\alpha$ Concentrations}

The concentration of total phosphorus (TP) presented the highest value of $0.131 \mathrm{mg} \cdot \mathrm{l}^{-1}$ in April 2005 in $40 \mathrm{~m}$ (station A). Statistically significant differences among the three sampling stations were found (Kruskal-Wallis test, $\mathrm{p}<0.05$ ), with station $\mathrm{C}$ presenting higher values. This station is in the part of the lake that is close to agricultural land and activities, which probably were responsi- 
ble for the greater enrichment of the water with phosphorus. A statistically significant difference (U-test, $\mathrm{p}<$ 0.05 ) in the TP concentrations between the two sampling periods was recorded, with higher values in the second period (September 2004-August 2005) in comparison to the third one (September 2005-August 2006). The same was also true for the concentrations of phosphates $\left(\mathrm{PO}_{4}\right)$ and also the nitrates $\left(\mathrm{NO}_{3}\right)$ between the two periods (U-test, $\mathrm{p}<0.05$ ), while no differences among stations concerning these two nutrients were found (KruskalWallis test, $\mathrm{p}>0.05$ ). The phosphates in the water fluctuated between undetected values to $0.095 \mathrm{mg} \cdot \mathrm{l}^{-1}$ (Figure 3). Nitrates $\left(\mathrm{NO}_{3}\right)$ and nitrites $\left(\mathrm{NO}_{2}\right)$ showed intense temporal variation and their concentrations fluctuated between undetected values to 0.718 and 0.058 $\mathrm{mg} \cdot \mathrm{l}^{-1}$ in July 2005 (station B, $30 \mathrm{~m}$ ) and in November 2005 (station A, $40 \mathrm{~m}$ ), respectively. The concentration of ammonia $\left(\mathrm{NH}_{4}\right)$ generally presented low values except in October 2004 when high values reaching up to 0.035 $\mathrm{mg} \cdot \mathrm{l}^{-1}$ were observed in the three sampling stations. There were no statistically significant differences between the two sampling periods for ammonia as well as for nitrates and nitrites (U-test, $\mathrm{p}>0.05$ ). Most of the above parameters presented considerably higher concentrations in comparison to the previous studies of Overbeck et al. [9], Koussouris et al. [10] and Tafas et al. [11] (Table 1). In particular, there was a remarkable increase of the maximum concentration of nutrients, such as TP (17.0\% - 1771\%), phosphates (36.0\% - 580.0\%), nitrates (59.6\% - 474.4\%) and nitrites (222.2\% - 1060\%). In addition, the present values for the average concentration of $T P$, nitrates and nitrites in the water column are higher than the respective values reported by Bertahas et al. [1] in their survey conducted in 2001-2002, while the average concentrations of phosphates and ammonia are lower. Ammonia has been increased by $43.4 \%$ in comparison to Overbeck et al. [9] (1982), but considerably decreased by $157.1 \%$ and $271.4 \%$ in comparison to Tafas et al. [11] and Koussouris et al. [10], respectively.

In the vertical axis, the general trend for most of the above chemical parameters was to present lower values in the epilimnion and higher in the meta-or/and the hypolimnion during the stratified period, while their concentration was more uniform during turnover (Figure $3)$. The higher $T P$ values in the hypolimnion were recorded during stratification and especially in the period of oxygen depletion, while during the mixing period higher concentrations were recorded just close to the bottom of the lake. The reason for this is probably the greater production of phosphorus due to decomposition of organic matter within the hypolimnion at the end of the stratification period (autumn), or/and to phosphorus release from the bottom sediment.

The concentrations of Chl- $\alpha$ fluctuated between 0.227 $\mu \mathrm{g} \cdot \mathrm{l}^{-1}$ in July 2006 at the surface to $9.37 \mu \mathrm{g} \cdot \mathrm{l}^{-1}$ in April 2006 in the $20 \mathrm{~m}$ of station A. Chl- $\alpha$ was always higher in the metalimnetic layer during the stratification period, while it was having a uniform distribution during the mixing period (Figure 4). No differences among the three stations were found (Kruskal-Wallis test, $\mathrm{p}>0.05$ ). The minimum Chl- $\alpha$ concentration reported in the present study was lower than the respective values in all the previous studies, while the present maximum value overcomes these of the past (Table 1 ).

\subsection{Trophic Classification}

The application of Carlson's index (TSI) revealed values between 25.7 - 67.5 for total phosphorus $\left(T S I_{T P}\right), 23.0$ 40.0 for transparency $\left(T S I_{S D}\right)$ and 15.2 - 47.5 for $C h l-\alpha$, (TSI Chl-a $_{\text {a }}$ considering all sampling stations (Figure 5). No statistically significant differences among the three sampling stations for $T S I_{T P}, T S I_{S D}$ and the total $T S I$ were found, although the $T S I_{C h l-a}$ values for station C were significantly higher that of the other two stations (Kruskal-Wallis test, $\mathrm{p}<0.05$ ). The results from the three sampling stations showed that Lake Trichonis is classified to the oligotrophic lakes according to the transparency measurements, while according to Chl- $\alpha$, it is classified as oligotrophic to mesotrophic, when the use of $T S I_{T P}$ classifies the lake to mesotrophic and sometimes eutrophic level. Finally, the overall Carlson's TSI index fluctuated between 24.3 and 45.4 having an average of 36.4 which classifies Lake Trichonis to the oligotrophic level.

\subsection{Zooplankton Composition and Abundance}

The mean integrated abundance of the total zooplankton in the water column of the three sampling stations varied between 2.55 to 131.9 ind $\mathrm{l}^{-1}$. Statistically significant abundance differences among the three sampling periods were found (Kruskal-Wallis test, $\mathrm{p}<0.05$ ), with the first period (September 2003-August 2004) presenting the lowest mean value. In contrast, no differences among the three stations (at the $0-20 \mathrm{~m}$ depth range) for any of the

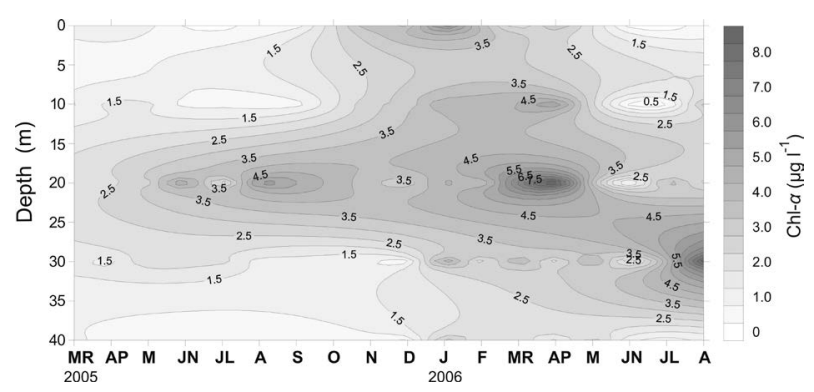

Figure 4. Vertical profiles of the concentrations of chlorophyll- $\alpha$ in the deeper sampling station A of Lake Trichonis during March 2005 - August 2006. 
sampling periods were recorded (Kruskal-Wallis test, $\mathrm{p}>$ 0.05). This was possibly due to the strong hydrological homogeneity along the horizontal axis of the lake, as a result of currents, surface seiche, water inflows and outflows [7,21]. Generally, the abundance values recorded in the present study were greater compared to other great oligotrophic lakes of the southern Europe, such as Lake Ohrid [22], Lake Tavropos [23] and Lake Bracciano [24]. On the other hand, the zooplankton abundance is lower than other eutrophic lakes of Greece like Lake Volvi [25], Lake Mikri Prespa [26], Lake Pamvotis [27], as well as the nearby eutrophic Lake Lysimachia [28] and the mesotrophic Lake Amvrakia [29]. The temporal variation of the total zooplankton was characterized by a decrease of abundance after September with lowest values in winter, while a first increase in spring due to rotifers and a second one in summer due to copepods. This variation did not seem to follow the monoacmic pattern (only one peak of abundance in summer) which is characteristic of the oligotrophic lakes according to the PEG model [30].

The zooplankton community in Lake Trichonis was consisted of the groups of rotifers, copepods, cladocerans and the larvae of molluscs (Figure 6). In particular, the three-year investigation revealed 25 species of rotifers, three copepod species, seven cladocerans and the larvae of the mollusc Dreissena blanci $[8,13]$. Copepods, and especially the calanoid Eudiaptomus drieschi, prevailed in the zooplankton community accounting for an average proportion of $50.0 \%$, followed by rotifers $(24.0 \%)$, cladocerans (15.6\%) and the mollusc larvae (10.4\%). E. drieschi also dominated the crustacean community (copepods and cladocerans) accounting on average for $65.6 \%$, while the contribution of cladocerans and the cyclopoid copepods varied between $1.5 \%$ to $67.7 \%$ and $0.1 \%$ to $14.9 \%$, respectively (Figure 7 ). The domination of calanoida among the crustaceans, which was observed during the three-year of investigation in Lake Trichonis, is characteristic of oligotrophic lakes [31-33]. In comparison to the past, however, the percentage of calanoida in the crustacean community seems to have been decreased from $50 \%$ - $100 \%$ [10] to $22 \%$ - $88 \%$ in the present study, while cladocerans increased their contribution. In addition, the present species composition within the crustacean community is different compared to the reports of Koussouris et al. [10], with the presence of only one calanoid species, instead of three [10]. Furthermore, considering that increased contribution of cladocerans and cyclopoid copepods in the crustacean communities is characteristic of eutrophic lakes [34], the
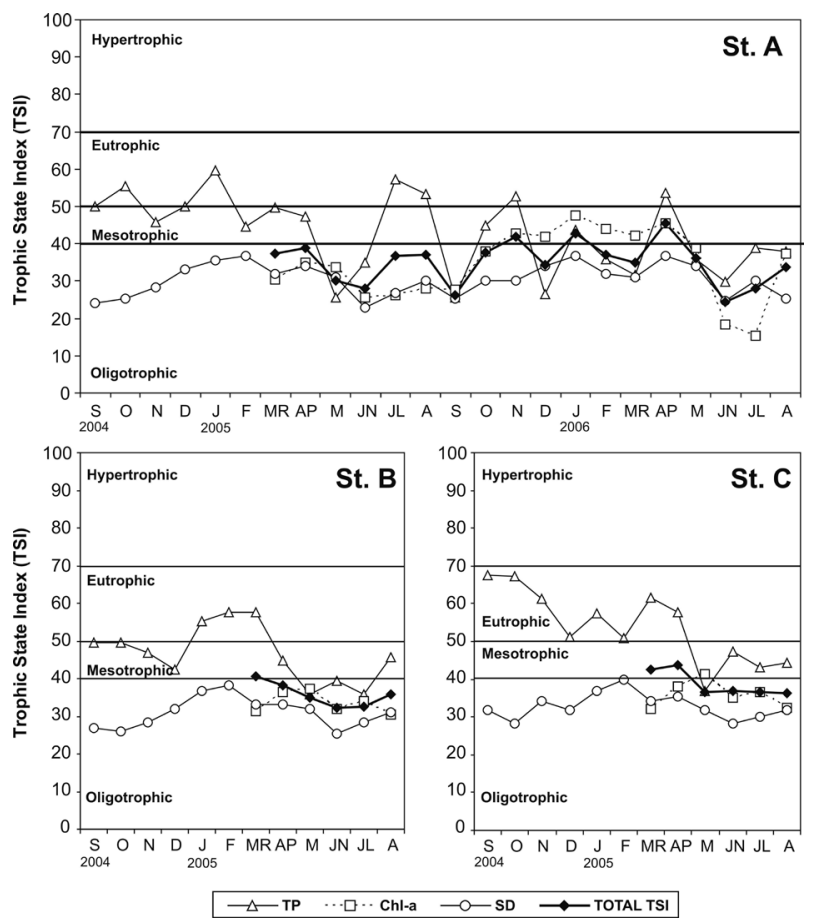

Figure 5. Monthly variation of the values of Carlson's TSI index for total phosphorus $\left(\right.$ TSI $\left._{\mathrm{TP}}\right)$, chlorophyll- $\alpha$ (TSI Chl-a $\left._{\text {a }}\right)$ and transparency $\left(T S I_{S D}\right)$, and also the overall TSI index (total TSI) in Lake Trichonis during September 2004 - August 2006 for station A, and during September 2004 - August 2005 for stations $B$ and $C$.

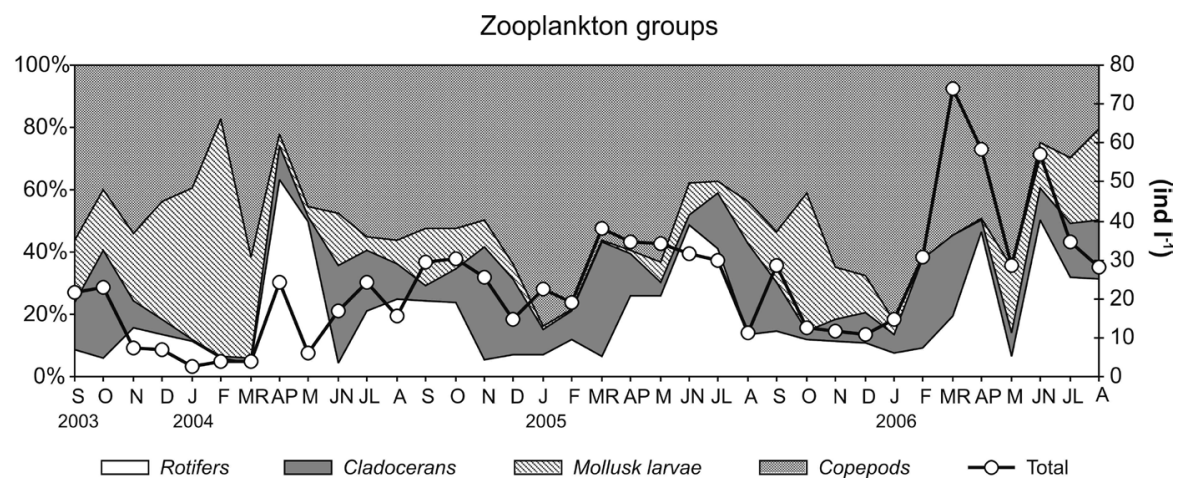

Figure 6. Monthly variation of the mean integrated $(0-40 \mathrm{~m})$ abundance of the total zooplankton (ind $\left.\mathrm{l}^{-1}\right)$ and percentage contribution of the main zooplanktonic groups (rotifers, cladocerans, copepods and mollusc larvae) to the total abundance recorded during September 2003 - August 2006 in station A of Lake Trichonis. 
decrease in the proportions of the calanoid copepods and the increase of cladocerans in Lake Trichonis could possibly indicate an alteration in its trophic condition.

Among the cladocerans, Diaphanosoma orghidani prevailed, accounting for an average of $50.9 \%$ in the community, and followed by Bosmina longirostris (25.6\%) and Daphnia sp. (22.2\%), while Ceriodaphnia pulchella, Alona sp. and Leptodora kindtii were found in small numbers and sporadically in the samples (Figure 8). A seasonal succession between $B$. longirostris which prevailed in the colder periods, and $D$. orghidani which prevailed in the warmer ones, was recorded. This type of succession in the community of cladocerans is similar to the situation described by Geller and Müller [35] for eutrophic lakes. However, this was apparent only during the first year, while in the second and third year two other cladocerans were added to the community and the succession of species was altered.

Among the zooplankton taxa found in Lake Trichonis during this extensive investigation, there were certain species which are considered indicators of either oligotrophic or eutrophic conditions (Table 2). Thus, the rotifers Brachionus calyciflorus, Filinia longiseta, Hexarthra mira, Keratella quadrata and Pompholyx sulcata, along with the cladocerans Bosmina longirostris and Daphnia cucullata are indicators of eutrophic conditions [36-39]. On the other hand, Kellicottia longispina and Ploesoma hudsoni of the rotifers and the cladocerans Daphnia galeata and Leptodora kindtii are indicators of oligotrophic conditions [38]. It must be pointed that, the percentage contribution of all the oligotrophic indicator species in the zooplankton of the lake ranged between $0.6 \%$ to $8.9 \%$ in the three sampling periods, while the respective range for the eutrophic species was $9.5 \%$ to $13.6 \%$. This resulted to an average of $7.5 \%$ for the oligotrophic and $10.6 \%$ for the eutrophic indicators in the overall sampling period. Furthermore, it is interesting to take a closer look to the presence of the cladocerans of the genus Daphnia sp., among which $D$. cucullata was the dominant species, while the abundance of D. galeata was an order of magnitude lower and it was found sporadically in the samples. The two species can hybridize and produce intermediate forms [19] and that is why we refer to them as Daphnia sp. Both species had not been found in Lake Trichonis according to the previous studies of Koussouris [40,41] and Koussouris et al. [10] conducted in 1975-1977 and in 1988-1989, respectively. Indeed, Kehayias et al. [12] were the first to report their

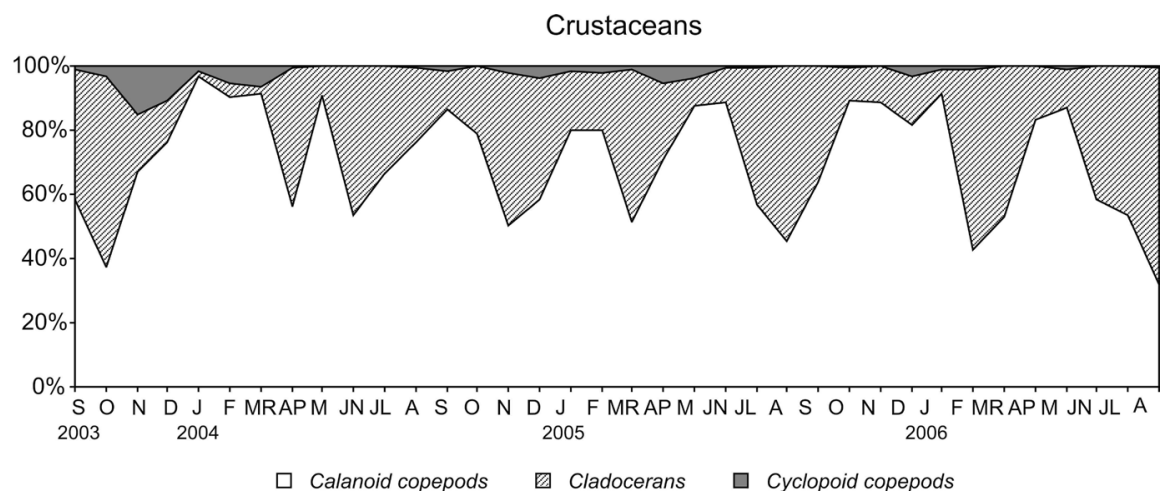

Figure 7. Average percentage contribution of the calanoid copepods, cladocerans and cyclopoid copepods to the crustacean community in Lake Trichonis (station A) during September 2003 - August 2006.

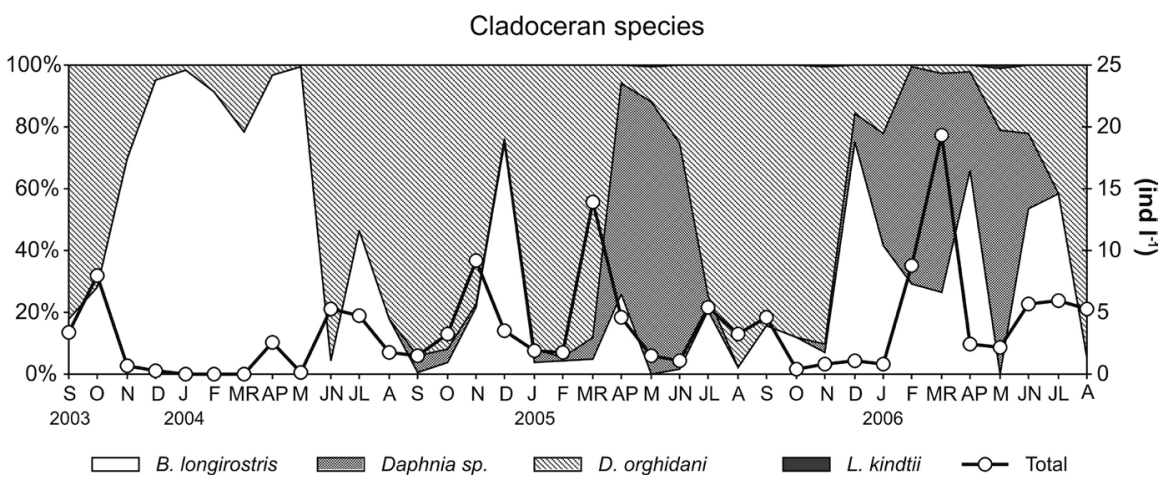

Figure 8. Monthly variation of the mean integrated $(0-40 \mathrm{~m})$ abundance of the total cladocerans (ind $\left.\mathrm{l}^{-1}\right)$ and percentage contribution of the most important species to the cladoceran's community recorded during September 2003 - August 2006 in station A of Lake Trichonis. 
Table 2. Indicator species of oligotrophic and eutrophic conditions [36-39] in Lake Trichonis.

\begin{tabular}{|c|c|c|}
\hline Species & Oligotrophic indicator & Eutrophic indicator \\
\hline \multicolumn{3}{|l|}{ ROTIFERA } \\
\hline Brachionus calyciflorus (Gosse 1851) & & $\mathrm{x}$ \\
\hline Filinia longiseta (Ehrenberg 1834) & & $\mathrm{x}$ \\
\hline Hexarthra mira (Hudson 1871) & & $\mathrm{x}$ \\
\hline Kellicottia longispina (Kellicott 1879) & $\mathrm{x}$ & \\
\hline Keratella quadrata (Müller 1786) & & $\mathrm{x}$ \\
\hline Ploesoma hudsoni (Imhof 1891) & $\mathrm{x}$ & \\
\hline Pompholyx sulcata (Hudson 1885) & & $\mathrm{x}$ \\
\hline \multicolumn{3}{|l|}{ CLADOCERA } \\
\hline Bosmina longirostris (O.F. Müller 1785) & & $\mathrm{x}$ \\
\hline Daphnia cucullata (G.O. Sars 1864) & & $\mathrm{x}$ \\
\hline Daphnia galeata (Sars 1864) & $\mathrm{x}$ & \\
\hline Leptodora kindtii (Focke 1844) & $\mathrm{x}$ & \\
\hline
\end{tabular}

presence in zooplankton samples taken just one year before the present investigation (2002-2003). D. cucullata is considered a typical representative of eutrophic lakes in Europe [39], while D. galeata is an indicator of oligotrophic conditions [38]. The characteristic body form and shape of $D$. cucullata makes almost impossible its misidentification if it had been caught in the samples during the previous studies. Thus, if the possibility of an accidental transfer of this species to the lake by human activities is excluded, the only reasonable explanation for its absence from the species lists in the past was that actually it was present in the lake but in undetected numbers, while during the last years there was an increase in its density. One reasonable explanation for its increase of abundance during the last decades could be the alteration of trophic condition of the lake towards higher levels, which favoured the development of a denser population. On the other hand, there is also a possibility of a preypredator relationship, in which the diminishing of the predation pressure on this species by its predator Atherina boyeri has resulted to prey recovery. According to the recent investigation of Doulka et al. [42], A. boyeri is the main zooplanktivorous predator in Lake Trichonis, where it exercises selective predation and D. cucullata is among its highly selected prey. Thus, a greater population of $A$. boyeri in the past could have diminished the population of $D$. cucullata, while the decrease of the former within the lake could result to the increase of the abundance of the latter. Though, there are not enough data to support this theory and more investigation on this issue is required.

\section{Conclusions}

The present investigation showed that Lake Trichonis seems to hold the main physicochemical features observed in the previous studies of Overbeck et al. [9], Koussouris et al. [10] and Tafas et al. [11], conducted between 15 to 25 years before the present investigation. However, in comparison to the above studies, there was an increase in the maximum values of most of the physicochemical parameters recorded in the present study, although their patterns of variation in the water column were similar. In particular, the maximum values of temperature, DO, conductivity and chlorophyll- $\alpha$ have been increased by $6.1 \%$ to $18.8 \%, 14.8 \%$ to $16.7 \%, 24.4 \%$ to $47.5 \%$ and $14.6 \%$ to $1075 \%$, respectively. Moreover, there was a considerable increase of the maximum concentration of nutrients, such as $T P$, phosphates, nitrates and nitrites. The lowest value of transparency in the present study was similar to the respective values reported by Tafas et al. [11] and Koussouris et al. [10], but was lower by $29.8 \%$ than the reports of Overbeck et al. [9].

Considering that Lake Trichonis is situated in an agricultural area, the elevated values of nutrients in the present study were probably related to the inflow of irrigation and drainage waters rich in residual fertilizers, which were used in the extensive cultivations during the past years [43]. The present higher values of $C h l-\alpha$, and as a by-product the increased DO in the metalimnetic layer, could be also the result of this chronic influx of nutrients into the lake. In accordance, the elevated productivity of the basin could be also among the reasons for the increase of conductivity [20], and this could have resulted to the lower values of water transparency in comparison to the oldest previous study of Overbeck et al. [9]. According to Bertahas et al. [1], phosphorus is the key nutrient that regulates eutrophication in Lake Trichonis as the limiting nutrient for algae growth. However, it seems 
that it is not the quantities of phosphorous entering the ecosystem but its hydrological regime which affects in a great extent its trophic status. In particular, the quantities of rainfall precipitation and water recharge are responsible for regulating the water outflow from the lake and consequently the phosphorus flush out of the system [1]. In this sense, the $T P$ fluctuation among years found in the present study could be originated to the variation of these hydrological elements in the lake's catchment area. On the other hand, the strong decrease in the concentrations of $T P$, phosphates and nitrates in the period of September 2005 - August 2006 in comparison to September 2004 August 2005, could be related to the termination of the tobacco cultivations during the former period. Tobacco cultivation was developed in the prefecture of Aitoloakarnania at the end of the $19^{\text {th }}$ century and this part of Greece became the country's major producing area of tobacco. However, from 1/1/2006 with the CAP reform in relation to tobacco cultivation, the overall production presented a significant reduction of about $80 \%$ in Greece and, specifically, $100 \%$ reduction in the whole prefecture of Aitoloakarnania [44]. As a result, tobacco producers either turned to other cultivations, or in most cases left their fields uncultivated. Although this pause in the agricultural activities has not been documented in details for the area, it is suggested that it could be among the reasons of the nutrients' decrease in the lake observed a year after this action.

Nevertheless, the nutrients' concentrations have been increased from the past the trophic level of the lake has not altered dramatically. Thus, although the previous investigators [1,9-11] did not use TSI index to have direct comparisons, they accounted Lake Trichonis as an oligoto mesotrophic aquatic ecosystem. The reason for this stability of the lake implies its large water volume and its positive water balance, as previously mentioned. On the other hand, the anthropogenic impacts on Lake Trichonis can be considered as low, in the sense that there are no heavy industrial units around or close to the lake. However, the existence of a large number of olive-oil refineries, as well as of several creameries and small livestock facilities like sheep and pig-farms, can be considered a constant thread for the increase of organic pollution entering the lake. In addition, the absence of biological treatment facilities for most of the surrounding villages, which probably result to undefined quantities of urban wastewater constantly dumping into the lake, are serious reasons of a future increase in lake's trophicity.

Consequently, the indications concerning the physicochemical elements of Lake Trichonis and its trophic state during the last thirty years point out a general stability and a strong resistance of the lake to trophic elevation. However, the present zooplankton investigation reveals a puzzling icon of the environmental state of the ecosystem, accumulating several indications. Thus, the total zooplankton abundance, the dominance of the calanoid copepods (instead of the cyclopoids or/and the rotifers) in the zooplankton community as well as among crustaceans, and the presence of certain indicator species, point out an oligotrophic character of the lake. On the other hand, the pattern of the temporal zooplankton variation and the seasonal succession pattern among cladoceran species resemble those reported from eutrophic lakes of Europe. Moreover, the appearance of "new" species, like $D$. cucullata, along with the disappearance of calanoid copepod species, the increase of the proportions of cladocerans among crustaceans in comparison to the past, and the increased proportions of indicator species of eutrophic conditions within the zooplankton community, may suggest that certain biological parameters have been altered from the past and indicate possibly a different ecological status of the lake. The bottom line could be that Lake Trichonis is probably experiencing a transitional condition towards the eutrophic state and thus, the need of constant inspection and monitoring not only of the abiotic parameters but also the biotic ones in the frame of a general management plan for this ecosystem, is indispensable.

\section{Acknowledgements}

This research was funded by the European Union in the framework of the program "Pythagoras II" of the "Operational Program for Education and Initial Vocational Training" of the $3^{\text {rd }}$ Community Support Framework of the Hellenic Ministry of Education, 25\% of which was funded from national sources, and 75\% from the European Social Fund (ESF).

\section{REFERENCES}

[1] I. Bertahas, E. Dimitriou, I. Karaouzas, S. Laschou and I. Zacharias, "Climate Change and Agricultural Pollution Effects on the Trophic Status of a Mediterranean Lake," Acta Hydrochimica et Hydrobiologica, Vol. 34, No. 4, 2006, pp. 349-359. http://dx.doi.org/10.1002/aheh.200500637

[2] R. E. Carlson, “A Trophic State Index for Lakes,” Limnology and Oceanography, Vol. 22, No. 2, 1977, pp. 361369. http://dx.doi.org/10.4319/lo.1977.22.2.0361

[3] R. C. Bailey, R. H. Norris and T. B. Reynoldson, "Bioassessment of Freshwater Ecosystems: Using the Reference Condition Approach,” Kluwer Academic Publishers, Dordrecht, 2004. http://dx.doi.org/10.1007/978-1-4419-8885-0

[4] W. Lampert and U. Sommer, "Limnoecology—-The Ecology of Lakes and Streams," Oxford University Press, Oxford, 1997.

[5] R. Caroni and K. Irvine, "The Potential of Zooplankton Communities for Ecological Assessment of Lakes: Re- 
dundant Concept or Political Oversight?” Biology and Environment: Proceedings of the Royal Irish Academy, Vol. 110, No. 1, 2010, pp. 35-53. http://dx.doi.org/10.3318/BIOE.2010.110.1.35

[6] E. Jeppesen, P. Nõges, T. A. Davidson, J. Haberman, T. Nõges, K. Blank, T. L. Lauridsen, M. Søndergaard, C. Sayer, R. Laugaste, L. S. Johansson, R. Bjerring and S. L. Amsinck, "Zooplankton as Indicators in Lakes: A Scientific-Based Plea for Including Zooplankton in the Ecological Quality Assessment of lakes according to the European Water Framework Directive (WFD)," Hydrobiologia, Vol. 676, No. 1, 2011, pp. 279-297. http://dx.doi.org/10.1007/s10750-011-0831-0

[7] I. Zacharias, E. Dimitriou and T. Koussouris, "Integrated Water Management Scenarios for Wetland Protection: Application in Trichonis Lake," Environmental Modelling and Software, Vol. 20, No. 2, 2005, pp. 177-185. http://dx.doi.org/10.1016/j.envsoft.2003.09.003

[8] E. Doulka, "Contribution to the Study of the Zooplankton Community of Lake Trichonis (Greece),” Ph.D. Dissertation, University of Ioannina, Agrinio, 2010.

[9] J. Overbeck, K. Anagnostidis and A. Economou-Amilli, "A Limnological Survey of three Greek Lakes: Trichonis, Lysimachia and Amvrakia," Archiv für Hydrobiologie, Vol. 95, No. 1-4, 1982, pp. 365-394.

[10] T. Koussouris, I. Bertahas, A. Diapoulis, V. Pakos and K. Gritzalis, "Limnological and Hydrobiological Characteristics of Lake Trichonis,” In: Daoulas, C., Ed., Limnological, Ichthyological and Fisheries Investigation of Lake Trichonis, NCMR Technical Report (TEE/144), Athens, 1993, pp. 1-37.

[11] T. Tafas, D. Danielidis, J. Overbeck and A. EconomouAmilli, "Limnological Survey of the Warm Monomictic Lake Trichonis (Central Western Greece). I. The Physical and Chemical Environment," Hydrobiologia, Vol. 344, No. 1-3, 1997, pp. 129-139. http://dx.doi.org/10.1023/A:1002914629984

[12] G. Kehayias, E. Michaloudi and A. Bexi, “Aspects on the Seasonal Dynamics and the Vertical Distribution of the Crustacean Zooplankton Community and the Dreissena polymorpha Larvae in Lake Trichonis,” Mediterranean Marine Science, Vol. 5, No. 1, 2004, pp. 5-17. http://dx.doi.org/10.12681/mms.206

[13] E. Doulka and G. Kehayias, "Spatial and Temporal Distribution of Zooplankton in Lake Trichonis (Greece)," Journal of Natural History, Vol. 42, No. 5-8, 2008, pp. 575-595. http://dx.doi.org/10.1080/00222930701835555

[14] APHA, AWWA and WPCF, "Standard Methods for the Examination of Water and Wastewater," American Public Health Association, Washington DC, 1998.

[15] V. M. Rylov, "Fauna of USSR. Crustacea. Freshwater Cyclopoida," Smithsonian Institution and National Science Foundation, Washington DC, 1963.

[16] A. Ruttner-Kolisko, "Plankton Rotifers. Biology Taxonomy," E. Schweizerbart'sche Verlagsbuchhandlung, Stuttgart, 1974.

[17] N. M. Korovchinsky, "Sididae and Holopediidae: (Crustacea: Daphniiphormes),” In: H. J. F. Dumont, Ed., Guide to the Identification of the Microinvertebrates of the Con- tinental Waters of the Word, SPB Academic Publishing, The Hague, 1992, pp. 1-82.

[18] M. Alonso, "Crustacea. Brachionopoda. Serie Fauna Ibérica,” Museo Nacional de Ciencias Naturales, CSIC, Madrid, 1996.

[19] J. A. H. Benzie, "Cladocerans: The Genus Daphnia (Including Daphniopsis),” In: Dumont, H. J. F., Ed., Guide to the Identification of the Microinvertebrates of the Continental Waters of the World, Vol. 21, Backhuys Publishers, Leiden, 2005, pp. 1-376.

[20] R. G. Wetzel, "Limnology. Lake and River Ecosystems," 3rd Edition, Academic Press, San Diego, 2001.

[21] I. Zacharias and G. Ferentinos, "A Numerical Model for the Winter Circulation in Lake Trichonis, Greece," Environmental Modelling and Software, Vol. 12, No. 4, 1997, pp. 311-321.

http://dx.doi.org/10.1016/S1364-8152(97)00021-2

[22] S. Stankovic, "The Balcan lake of Ohrid and Its Living World,” Uitgeverijdr. W. Junk, Den Haag, 1960.

[23] I. Tsekos, P. S. Economidis, S. Charitonidis, A. Sinis, G. Nikolaides, D. Petridis, M. Moustaka, M. Zarfdjian and A. Kokkinakis, "Hydrobiological Study of the Man-Made Lake Tavropou, Karditsa,”Final Report, Greek Ministry of Agriculture, Athens, 1992.

[24] O. Ferrara, D. Vagaggini and F. G. Margaritora, “Zooplankton Abundance and Diversity in Lake Bracciano, Latium, Italy,” Journal of Limnology, Vol. 61, No. 2, 2002, pp. 169-175. http://dx.doi.org/10.4081/jlimnol.2002.169

[25] M. H. Zarfdjian, "Seasonal Variation and Spatial Distribution of Planktonic Invertebrates in Lake Volvi (Macedonia, Greece),” Ph.D. Dissertation, Aristotle University, Thessaloniki, 1989.

[26] E. Michaloudi, M. Zarfdjian and P. S. Economidis, “The Zooplankton of Lake Mikri Prespa,” Hydrobiologia, Vol. 351, No. 1-3, 1997, pp. 77-94. http://dx.doi.org/10.1023/A:1003008306292

[27] J. R. Romero, I. Kagalou, J. Imberger, D. Hela, M. Kotti, A. Bartzokas, T. Albanis, N. Evmirides, S. Karkabounas, J. Papagiannis and A. Bithava, "Seasonal Water Quality of Shallow and Eutrophic Lake Pamvotis, Greece: Implications for Restoration,” Hydrobiologia, Vol. 474, No. 1-3, 2002, pp. 91-105. http://dx.doi.org/10.1023/A:1016569124312

[28] E. Chalkia and G. Kehayias, “Zooplankton and Environmental Factors of a Recovering Eutrophic Lake (Lysimachia Lake, Western Greece),” Biologia, Vol. 68, No. 3, 2013, pp. 459-469. http://dx.doi.org/10.2478/s11756-013-0171-9

[29] E. Chalkia, I. Zacharias, A-A. Thomatou and G. Kehayias, "Zooplankton Dynamics in a Gypsum Karst Lake and Interrelation with the Abiotic Environment," Biologia, Vol. 67, No. 1, 2012, pp. 151-163. http://dx.doi.org/10.2478/s11756-011-0147-6

[30] U. Sommer, Z. M. Gliwicz, W. Lampert and A. Duncan, "The PEG-Model of Seasonal Succession of Planktonic Events in Fresh Water,” Archiv für Hydrobiologie, Vol. 106, No. 4, 1986, pp. 433-471. 
[31] P. E. Sager and S. Richman, "Functional Interaction of Phytoplankton and Zooplankton along the Trophic Gradient in Green Bay, Lake Michigan,” Canadian Journal of Fisheries and Aquatic Sciences, Vol. 48, No. 1, 1991, pp. 116-122. http://dx.doi.org/10.1139/f91-016

[32] J. J. Elser and C. R. Goldman, "Zooplankton Effects on Phytoplankton in Lakes of Contrasting Trophic Status,” Limnology and Oceanography, Vol. 36, No. 1, 1991, pp. 64-90. http://dx.doi.org/10.4319/lo.1991.36.1.0064

[33] G. Maier, “Copepods Communities in Lakes of Varying Trophy Degree,” Archiv für Hydrobiologie, Vol. 136, No. 4, 1996, pp. 455-465.

[34] R. Pinto-Coelho, B. Pinel-Alloul, G. Méthot and K. E. Havens, "Crustacean Zooplankton in Lakes and Reservoirs of Temperate and Tropical Regions: Variation with Trophic Status," Canadian Journal of Fisheries and Aquatic Sciences, Vol. 62, No. 2, 2005, pp. 348-361. http://dx.doi.org/10.1139/f04-178

[35] W. Geller and H. Müller, "Seasonal Variability in the Relationship between Body Length and Individual Dry Weight as Related to Food abundances and Clutch Size in Two Coexisting Daphnia Species,” Journal of Plankton Research, Vol. 7, No. 1, 1985, pp. 1-18. http://dx.doi.org/10.1093/plankt/7.1.1

[36] J. E. Gannon and R. S. Stemberger, “Zooplankton (Especially Crustaceans and Rotifers) as Indicators of Water Quality," Transactions of American Microscopy Society, Vol. 97, No. 1, 1978, pp. 16-35. http://dx.doi.org/10.2307/3225681

[37] A. Mäemets, "Rotifers as Indicators of Lakes Types in Estonia,” Hydrobiologia, Vol. 104, No. 1, 1983, pp. 357-
361. http://dx.doi.org/10.1007/BF00045991

[38] B. Pejler, "Zooplanktonic Indicators of Trophy and Their Food,” Hydrobiologia, Vol. 101, No. 1-2, 1983, pp. 111114. http://dx.doi.org/10.1007/BF00008662

[39] Z. M. Gliwicz and W. Lampert, "Food Thresholds in Daphnia Species in the Absence and Presence of BlueGreen Filaments,” Ecology, Vol. 71, No. 2, 1990, pp. 691-702. http://dx.doi.org/10.2307/1940323

[40] T. Koussouris, "Plankton Observations in Three Lakes of Western Greece,” Thalassographica, Vol. 2, No. 1, 1978, pp. 115-123.

[41] T. Koussouris, "Dominating Planktonic Rotatoria in Some Lakes of Western Greece," Biologia Gallo- Hellenica, Vol. 12, No. 1, 1979, pp. 135-140.

[42] E. Doulka, G. Kehayias, E. Chalkia and I. Leonardos, "Feeding Strategies of Atherina boyeri (Risso 1810) in a Freshwater Ecosystem,” Journal of Applied Ichthyology, Vol. 29, No. 1, 2013, pp. 200-207. http://dx.doi.org/10.1111/jai.12012

[43] E. Dimitriou, I. Zacharias and T. Koussouris, "Study for the Water Balance of Trichonis Lake Catchments," In: Zacharias, I. and Koussouris, T., Eds., Actions for the Protection of Calcareous Bogs/Fens in Trichonis Lake, Technical Report, NCMR/IIW, Athens, 2001, pp. 1-111.

[44] A-A. Thomatou, M. Triantafyllidou, E. Chalkia, G. Kehayias, I. Konstantinou and I. Zacharias, "Land Use Changes Do Not Rapidly Change the Trophic State of a Deep Lake. Amvrakia Lake, Greece,” Journal of Environmental Protection, Vol. 4, No. 5, 2013, pp. 426-434. http://dx.doi.org/10.4236/jep.2013.45051 